\title{
A Study on the Urban Redevelopment of Ovidiu's Shoreline
}

\author{
Nicolae-Costin Mociu
}

\begin{abstract}
This study adds to what most studies lack in understanding the process and context of urban regeneration. Only by understanding the local, national, and global contexts and processes of urban regeneration can inferences, lessons, and best practices be made. The objective of this study is to review the literature on urban regeneration and evaluate contemporary alterations and their implications for future city renewal. The rehabilitation of Ovidiu's waterfront is a unique issue, considering the city's location, its openness to Lake Siutghiol, which is separated from the Black Sea by only a $400 \mathrm{~m}$ wide cordon, and the presence of the Roman camp and the aqueduct that previously supplied the Roman castle of Tomis. Lake Siutghiol has considerable growth potential due to the direct connection between Ovidiu and Mamaia, a popular tourist destination recently attracting many investors.
\end{abstract}

Keywords - city renewal, GIS, lake, urban planning

\section{INTRODUCTION}

Over time, history has demonstrated that opening a city to water is regarded a benefit, either tactically in terms of supply and defense, or because it creates a site that may become an attraction for city residents and a distinctive residential neighborhood via its harmonious development.

Urban waterfront revitalization is a critical component of late twentieth-century urban architecture and planning [1].

The urban shoreline has undergone tremendous alteration in recent years, with the potential to attract new investment and revitalize the local economy.

Today, an increasing number of coastal communities worldwide are being inspired by the concept of reintroducing water into the city and attaining excellent development via a combination of structures and activities [2].

In this environment, the waterfront has emerged as a significant site for architectural and urban planning innovation, with a significant impact on the field.

The urban redevelopment of the waterfront, according to Dovey [1] represents a significant potential, but it may also be a significant difficulty.

On the one hand, it has the ability to restore a city's identity and to reinforce the sense of place that people have about a location. As an alternative, it may result in the construction of isolated developments on the fringes of the city. 


\section{sciendo}

134 Ovidius University Annals Series: Civil Engineering, Year 23, 2021

\subsection{Location of the study area}

Located north of Constanţa, in the immediate vicinity of the Poarta Albă - Midia Canal, Năvodari and Mihail Kogălniceanu International Airport, and crossed by the European road E60 (national road 2A), the city of Ovidiu is located, geographically, on the coordinates $44^{\circ} 16^{\prime} 12$ "north latitude and $28^{\circ} 33^{\prime} 36^{\prime \prime}$ east longitude. It borders, near Constanţa, with the city of Năvodari and the communes of Lumina, Mihail Kogălniceanu, Poarta Albă and Valu lui Traian [3].

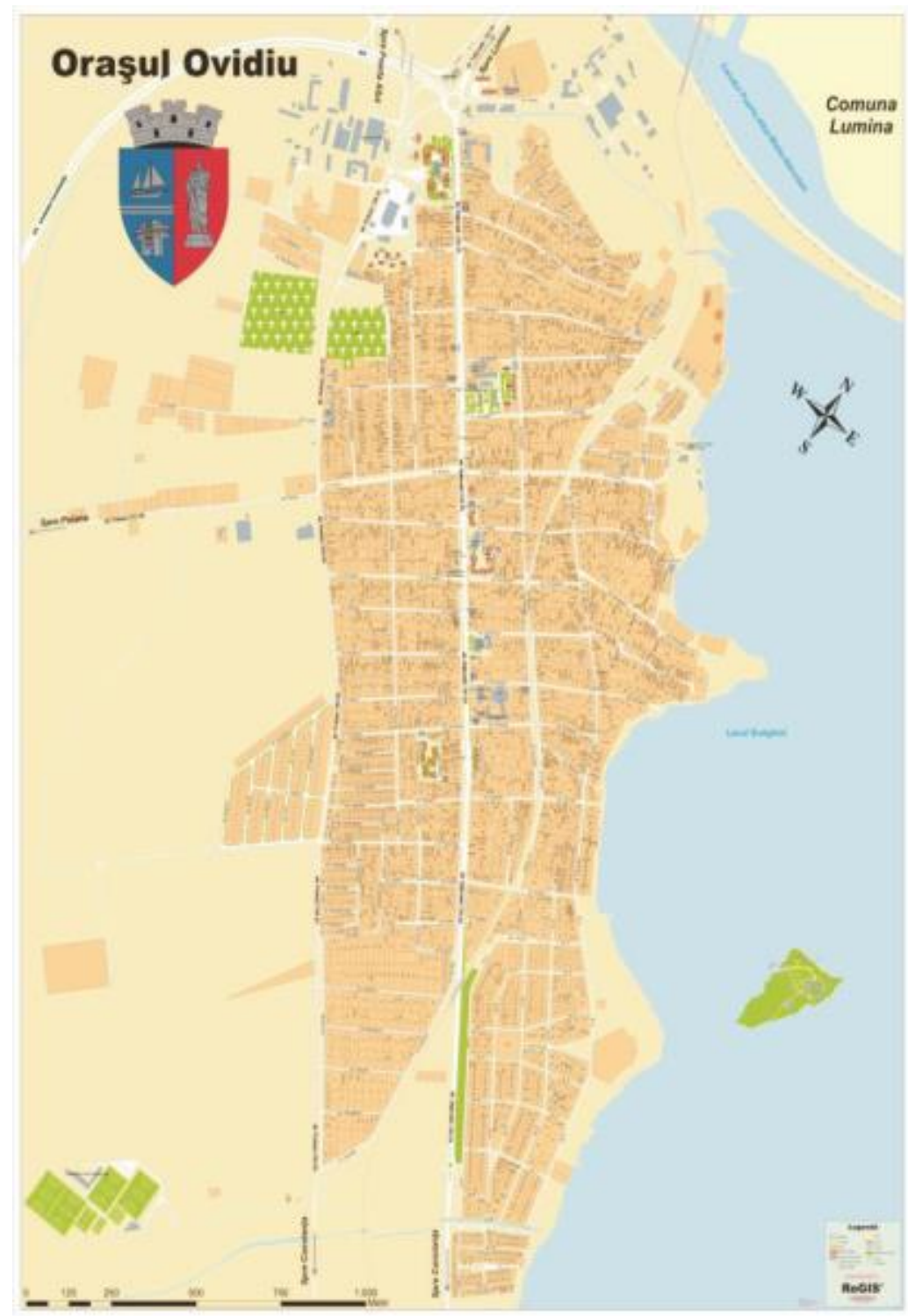

Fig. 1. Ovidiu city map 


\section{sciendo}

\subsection{Hydrography}

Lake Siutghiol, which covers an area of $19.5 \mathrm{~km} 2$, is a lagoon isolated from the sea by a variable-width coastal cordon, inside the confines of which was subsequently established the resort of Mamaia, which is now a part of Constanta.

The lake is filled with fresh water and is fed by underground sources, with flows ranging between 900 and 12501 / s, and its level is higher than the Black Sea's.

Between 1925 and 1927, a covered concrete canal was created between Siutghiol and Taşaul lakes to equalize the latter's water volume.

It has a water capacity of around 90 million cubic meters, which varies both multiannually and within a single year, depending on the ratio of water supply (underground and surface) to consumption, evaporation, and infiltration via the coastal cordon, among other factors.

Until 1950, Lake Siutghiol had a reasonably steady hydrodynamic equilibrium and a low level of pollution, despite its considerable fishing potential.

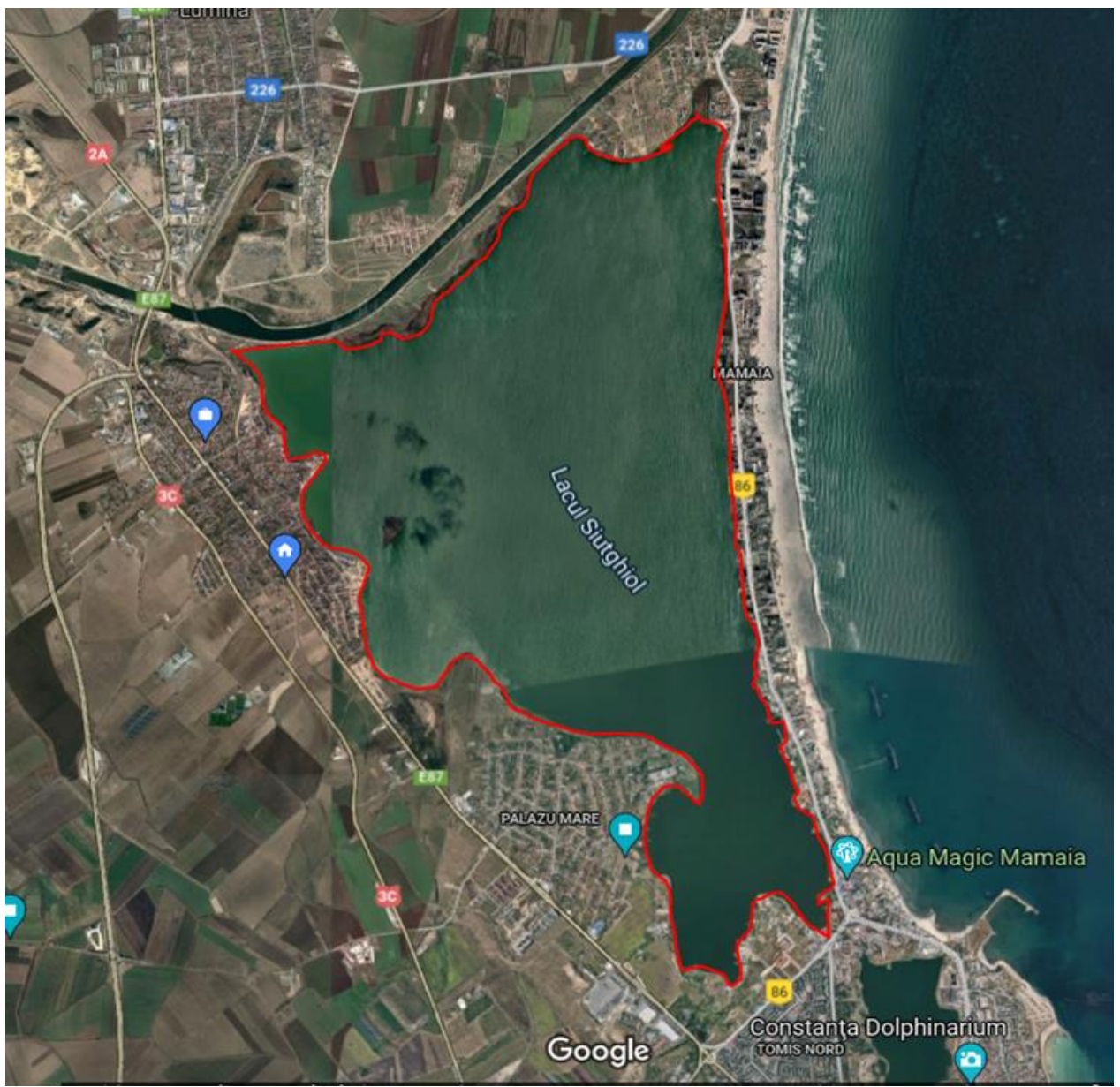

Fig. 2. Siutghiol Lake Basin 


\section{sciendo}

136 Ovidius University Annals Series: Civil Engineering, Year 23, 2021

\section{PURPOSE AND OBJECTIVES}

Given the gaps in the research already mentioned, this paper will examine the issue of waterfront urban revitalization. It is located in Romania, in the city of Ovidiu.

The research will focus primarily on the regeneration of the region around the beaches of Lake Siutghiol in Ovidiu, but will also examine other places of interest in the city. This is the sole means to uncover and debate previously unknown features and aspects of the waterfront regeneration process.

Due to the fact that the entire research area is devoted to the city of Ovidiu, which is relatively small in size, one could argue that the research's conclusions are extremely limited to the case study itself, or that the solutions attempted or supported in Ovidiu have little relevance for other cities.

Indeed, this is not totally true; because a number of general principles and models of excellent practice may be recognized and utilized in other similar regions as well as in the execution of future urban waterfront redevelopment projects.

\section{RESEARCH METHODOLOGY}

In this case study, we used a strategy that allowed us to investigate the coastline of Lake Siutghiol from a number of perspectives and using a range of sources of information.

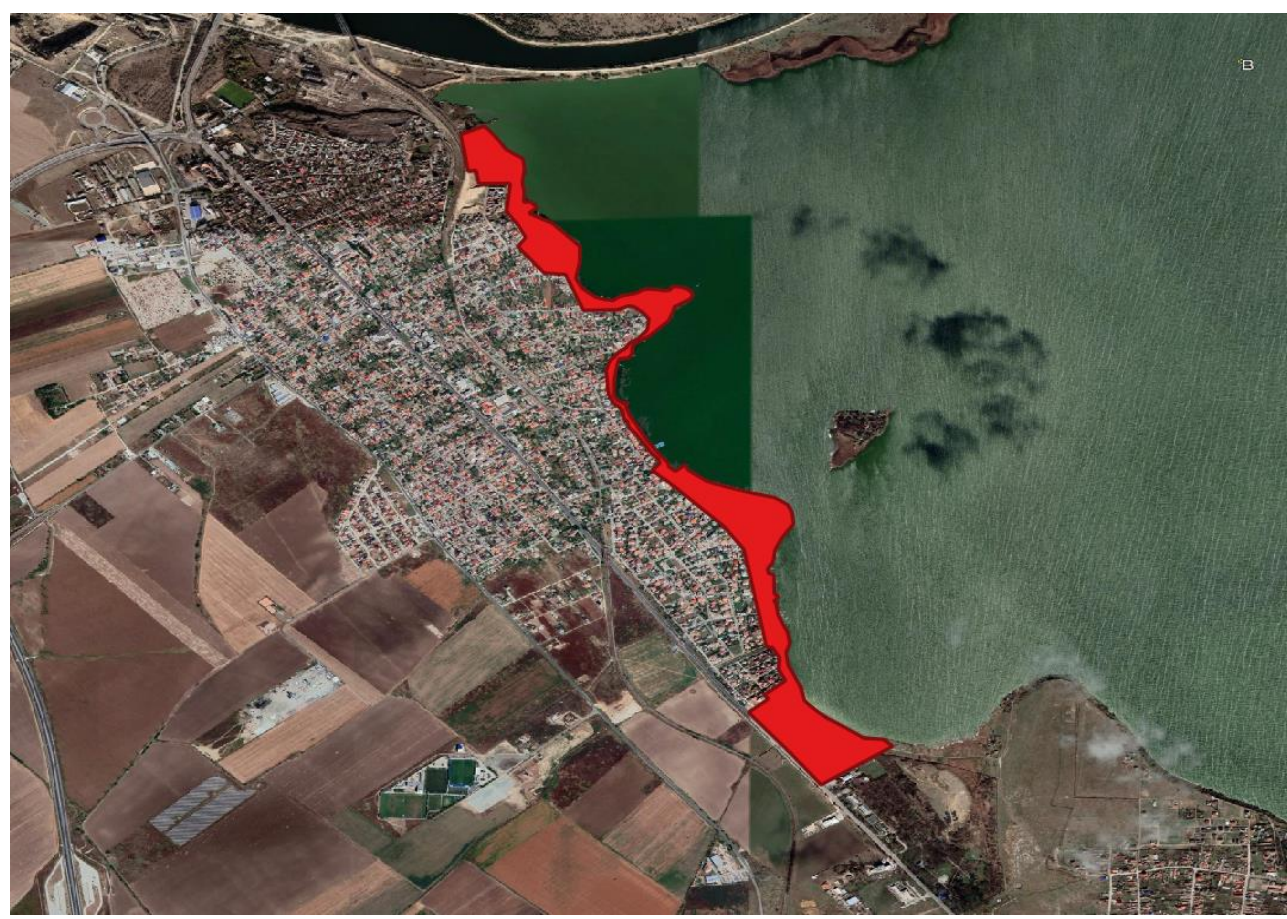

Fig. 3. Highlighted waterfront zone that is in development

Before collecting all of the data, however, it was necessary to establish a theoretical framework to tie the case together and verify that the data collection technique could be 
traced back to the original source. Aside from that, the theoretical framework was essential for understanding and interpreting the data results.

The findings of the study are backed by a number of sources of evidence (documents, direct observation and collection of news articles).

Reports, plans, administrative papers, earlier research on the same case study, maps, and historical literature have all been important in supplying the study with consistent data that can be studied again.

The records aided in comprehending the whole process of shoreline transformation and also aided in comprehending the pattern, themes, and difficulties associated with the coast of Lake Siutghiol.

Another source of information is news stories about the long-term transformation of the coastline of Lake Ovidiu. While the collection has significant drawbacks, it provides critical historical information and an analysis of the city's recovery process.

Additionally, the use of GIS programs enabled the comparison of maps from various time periods in order to highlight the area of interest on the lake shore as well as construction projects developed in this location over the years, both public and private, that resulted in an extraordinary development of the coast, but also of the city.

\section{CONCLUSIONS}

Increasingly essential in the growth of contemporary cities is urban regeneration, and in the case of Ovidiu, by implementing real estate projects, but also projects of public utility, such as parks and leisure spaces, the appearance of the city from the lake has been significantly improved.

Having a large number of people choose to relocate here, as well as an increase in the area's importance and attractiveness as a result of the increased importance and attractiveness to visitors, has resulted in an exceptional development of the region surrounding it.

As a result of the increased importance and attractiveness to visitors, the lake has resulted in a population expansion as a result of many people choosing to relocate here.

The coastal region has been separated into seven subzones, each of which has residential complexes, parks, and commercial districts.

This has been done in order to promote development. In addition, an examination of data from the 1999 and 2019 general urban plans, which show a rise in the urban area from 1072.03 hectares [4] to 1325.85 hectares, respectively, illustrates the importance of the lake's presence in the city's development.

A considerable number of new projects have been completed, and there has been an ongoing demand for additional houses, which are primarily centered around the lake, resulting in the city experiencing tremendous growth.

The archeological site of the Roman camp, which is located on the banks of Lake Siutghiol and not far from it, is a highly important place since it served as the supply of water for the Roman aqueduct that connected the castle of Tomis to the rest of the world.

Earlier this year, a European initiative was completed with the goal of improving the Roman camp.

This project's goal was to raise awareness of the camp, conserve it, and turn it into an open-air museum. 


\section{REFERENCES}

[1] DOVEY, K. 2005. Fluid City; Transforming Melbourne's Urban Waterfront, Sydney, Australia UNSW PressShaw, 2001

[2] JONES, A. 1998. Issues in Waterfront Regeneration: More Sobering Thoughts-A UK Perspective. Planning Practice and Research, 13, 433-442

[3] Primaria Ovidiu, 2016, Strategia de dezvoltare durabila a orasului Ovidiu

[4] SC Mina-M-Com SRL, 2019. Memoriu General, Plan Urbanistic General oras Ovidiu. 10-13

Note:

Nicolae-Costin Mociu - PhD, Ovidius University of Constanta, Bd. Mamaia nr. 124, 900356-Constanta, Romania (corresponding author to provide tel:+40722 246 057; e-mail: costin.mociu@365.univ-ovidius.ro) 